\title{
Brucella Strains from Mouselike Rodents in Southwestern USSR
}

\author{
P. A. VERSHILOVA, * G. I. LIAMKIN, V. E. MALIKOV, E. A. DRANOVSKAYA, AND I. F. TARAN \\ Gamaleya Institute of Epidemiology and Microbiology, Academy of Medical Science, Moscow, and Plague \\ Control Institute of the Caucasus and Transcaucasia, Stavropol, U.S.S.R.
}

\begin{abstract}
Brucella strains isolated from mouselike rodents in the northern foothills of the Large Caucasus are phenotypically similar to Brucella suis. On the basis of several differential characteristics, these strains are considered to be a new biotype of $B$. suis.
\end{abstract}

During the last 20 years, strains of Brucella have been recovered from some species of mice and mouselike rodents (Apodemus agrarius Pall., Mus musculus L., Apodemus sylvaticus L., Microtus arvalis Pall., Micromys minutus Pall.) in the northern foothills of the Large Caucasus. Investigations of these strains by several workers $(1,2,6)$ produced contrasting opinions concerning the taxonomic position of these isolates.

In this paper we report the results of taxonomic studies of rodent strains of Brucella that were conducted as recommended by the Subcommittee on Taxonomy of the genus Brucella (3).

A total of 66 Brucella strains isolated from mouselike rodents in S-form were selected for this study. International reference strains Brucella melitensis $16-\mathrm{M}^{\mathrm{T}}$ (type strain) biotype 1 , Brucella abortus $544^{\mathrm{T}}$ biotype 1 , Brucella suis $1330^{\mathrm{T}}$ biotype $1, B$. suis Thomsen biotype $2, B$. suis 686 biotype 3 , and $B$. suis 40 biotype 4 were used for comparison. These strains were obtained from the Laboratory of Brucellosis, $\mathrm{Ga}$ maleya Institute of Epidemiology and Microbiology, Moscow.

The morphological and staining characteristics of the rodent strains were typical of Brucella. Cultures grew aerobically and did not produce hydrogen sulfide. The rodent isolates studied, as well as the other Brucella strains, hydrolyzed urea and contained neuraminidase with an activity of $135 \mathrm{HE}$. All strains grew in the presence of thionine at standard concentrations of 1:25,000,1:50,000, and 1:100,000. Growth was inhibited by basic fuchsin (1:50,000, $1: 100,000)$. The rodent strains were lysed by brucellaphages $\mathrm{Wb}$ (Weybridge) and $\mathrm{Bk}_{2}$ (Berkeley) at 1 and $10^{4}$ routine test dilutions and by phages $\mathrm{Tb}$ (Tbilisi) and Fi (Firenze) only at $10^{4}$ routine test dilutions, which is characteristic of $B$. suis. These strains were agglutinated with monospecific anti-B. melitensis serum at a titer of $1: 320$, but not with anti-B. abortus serum. These results differentiate the rodent strains from the previously described biotypes of $B$. suis. Oxidative metabolism tests $(5)$ showed that the rodent strains oxidized $\mathrm{L}$-arginine, $\mathrm{DL}$-ornithine, DL-citrulline, and L-lysine. Oxidation of these substrates is characteristic of $B$. suis. However, unlike $B$. suis, the rodent strains also oxidized L-alanine, L-asparagine, and L-glutamic acid. Standard concentrations of pyronin B $(1: 800,000)$, safranin $T(1: 500,000)$, gentian violet $(1: 500,000)$, and crystal violet $(1: 2,000,000)$ suppressed growth of the rodent strains but did not inhibit growth of the reference strains. This feature differentiates the rodent strains. The lipopolysaccharides from the rodent strains were similar to those of the reference strain of $B$. suis in chemical composition, antigenic structure, and toxicity for white mice.

An investigation of the protein spectra of Brucella strains by disc gel electrophoresis in polyacrylamide gels (4) showed that the Brucella strains isolated from mouselike rodents had proteinograms identical to those of reference strains of $B$. suis characterized by the presence of fractions with an $R_{f}$ value of 0.85 .

Thus, the ability to agglutinate with monospecific anti- $B$. melitensis serum, the greater susceptibility to pyronin $B$, safranin $T$, gentian violet, and crystal violet, and the ability to oxidize L-alanine, L-asparagine, L-glutamic acid, L-arginine, DL-ornithine, DL-citrulline, and Llysine indicate that the rodent strains comprise an independent biotype of $B$. suis. We designate strain B. suis 514 of our collection as the representative reference strain.

\section{LITERATURE CITED}

1. Dranovskaya, E. A. 1974. Some biochemical properties of brucella and their importance for differentiation of individ- 
ual species of the genus Brucella and their taxonomic position. J. Microbiol. Epidemiol. Immunobiol. (USSR) 7:17-23. (In Russian.)

2. Dushina, O. P., L. I. Mitrofanova, E. N. Chudentsova, and N. T. Savchenko. 1964. Isolation of atypical brucella from murine rodents in the Chechen-Ingush Autonomous Republic. J. Microbiol. Epidemiol. Immunobiol. (USSR) 3:143-144. (In Russian.)

3. International Committee on Systematic Bacteriology, Subcommittee on Taxonomy of Brucella. 1982. Minutes of the meeting, 4 and 5 September 1978. Int. J. Syst. Bacteriol. 32:260-261.
4. Maurer, H. 1971. Disc-electrophoresis: theory and practice of electrophoresis in polyacrylamide gels. Moscow. (Russian translation from German.)

5. Meyer, M. E., and H. S. Cameron. 1961. Metabolic characterization of the genus Brucella. II. Oxidative metabolic patterns of the described biotypes. J. Bacteriol. 82:396400.

6. Taran, I. F., and E. I. Zamakhaeva. 1971. A comparative study of $B$. suis strains isolated from animals of different species. J. Microbiol. Epidemiol. Immunobiol. (USSR) 7:140-143. (In Russian.) 